Page 708-717. ISBN: 978-602-6 988-75-1

Web Jurnal Online: jurnal.unmuhjember.ac.id

By: Agus Nurulsyam Suparman; Asep Nurdin; Intan Apriliani

Community Empowerment of Politics In Creating Public Leadership

(Analysis The Performance Members DPRD of Ciamis District In The Election 2019)

\title{
COMMUNITY EMPOWERMENT OF POLITICS \\ IN CREATING PUBLIC LEADERSHIP \\ (ANALYSIS THE PERFORMANCE MEMBERS DPRD OF CIAMIS DISTRICT IN THE ELECTION 2019)
}

\author{
Agus Nurulsyam Suparman ${ }^{1}$, Asep Nurdin ${ }^{2}$, Intan Apriliani $^{3}$ \\ ${ }^{123)}$ Government Science Study Program \\ Faculty of Social Science and Political Science \\ Universitas Galuh \\ e-mail :agusnurulsyams@gmail.com
}

\begin{abstract}
The purpose of this study is to determine the ability and independence of the community in political empowerment so that the community can play a role in determining public policy. The method used is a qualitative descriptive approach method based on the results of observations, interviews and documentation studies. The results of the study show that the implementation of political empowerment which has been carried out by Ciamis Regency DPRD members, especially during the recess period before the 2019 General Election whose implications for creating public leadership cadres from the community in the future, is limited to more unilateral interests. leaning towards strengthening and increasing the voice of support, while the main substance directed at encouraging people to participate in determining and having the capacity to provide aspirations, especially to produce public policy products that are in favor of the interests of society is still far from expectations. Likewise from the expected implications in producing cadres of public leaders from the community, especially as a generation who are able to understand politics as part of the life of the nation, especially as a strategy to make regional changes to be more independent and improve welfare still need coordinated and sustainable efforts involving various aspects of stakeholders (government and other political actors).
\end{abstract}

Keywords: Empowerment, Politics, Public Leadership. 


\section{INTRODUCTION}

In a sovereign government, the social aspect of people's lives has the main role as a unifier because it is an integral part and as one of the conditions for the establishment and legitimacy of a country, therefore the life of the nation is a parameter to measure the success and dignity of the country. This reality is seen as an illustration of the true face of the country. So that the main key as a unifier of the nation lies in the departure between the life of the state and the life felt by the community.

The state which is a manifestation of political life from the community which is equipped with the power to formulate and realize the public interest must certainly be able to regulate and run the government as the sole ruler of the state manager so that it is able to achieve its function. Furthermore, when connected between the functions of the state and the democratic system adopted by the Unitary State of the Republic of Indonesia, there is an association, namely people's sovereignty really manifests into a system of government, because people's aspirations and interests are made as a central position not only theoretically but also operationally. This is evident from every aspect in the administration of government tends to emphasize democracy as the main idea in exercising power. In line with the development and mushrooming of the term democracy which is seen as a feature of modern society, various kinds of thoughts arise about democracy and its various implications. Historically democracy can be defined as the government from the people, by the people and for the people (Government of the people, by the people and for the people).

Sorensen (1993) in Sahid (2011: 305) classifies the notion of democracy in two ways, namely narrowly and comprehensively. Democracy is narrowly defined as a mechanism for choosing political leaders. The mechanism is a general election. Conceptualized by Huntington, 1991) in his thesis that in this case democracy is not something that is merely formal-procedural, but rather an instrument to implement the principles of freedom in competing and participating in choosing and being chosen.

In addition, political transpiration from authoritarian birocratic power regimes into democratic politics, which is marked by the release of political party control from the government, has created a multi-party system as the starting point of party growth based on political interests and orientation. The political party's enthusiasm is shown by a large number of political parties participating in each election administration, both at the national level and at the local level (local government).

In the context of democracy, popular sovereignty is the main key so that community participation as the holder of sovereignty has a very important role in determining leaders, various efforts are made to increase public participation so that democratic values are maintained, political participation is taking part or participating in the process political process in a political system, political participation can be part of the political empowerment of society, because an empowered society will be able to create leadership that is expected and desired by the community in carrying out people's sovereignty.

Understanding self-empowerment according to Prijono (1996: 97), Empowerment is a development concept that has the meaning of development, 
independence, self-reliance and strengthening the bargaining position of the grassroots community towards forces in all sectors and sectors of life. Based on the above definition, it can be understood that community political empowerment is a way to empower and strengthen the community, which is directed to have a bargaining position and be able to control their lives to protect people's sovereignty in the state, political empowerment of the community can produce an independent society. stronger than the influencing forces around it to determine better leadership.

In line with this view, as from the results of observations on the implementation of legislative elections to elect members of the Ciamis Regency Regional Representative Council (DPRD) held in 2019, there is a phenomenon of changes in political behavior of legislative members who in fact are administrators of political parties and have caused the shift of navigation routes within political parties. Then, the patterns of political leadership developed by members of the legislature have recently begun to abandon dogmatic values contained in party political ideology and displaced by fragmented values which are much influenced by political deals that sometimes do not in line with the function of the political party itself, as a result of a decrease in the attitude of loyalty and concern among fellow political party officials.

This can be seen from the performance of the members of the Ciamis Regency legislature, which on the one hand as administrators of political parties and on the other hand as representatives of the community parliaments are always in the implementation that tend to have two different demands as a form of legalization to maintain power. On the one hand, it accommodates the demands of the political participation of the community, and its values are of interest to provide a place for political elite groups to always occupy important positions in the government. Meanwhile, when viewed under Article 149 of Law Number 23 of 2014, it states that: DPRD has functions: (a) legislative functions, (b) supervisory functions, and (c) budget functions which basically as a form of representation from the community seem increasingly distant from real hope.

So far, those who often get critical attention from the public, namely, related to the function of the regional legislative council (DPRD) in budgeting are certainly related to how the role of the DPR in preparing the state budget should be in accordance with the aspirations of each accountable allocation for various development sectors. and transparent so that it can prevent wastage and irregularities since the development planning process, but it tends to create a variety of policies, especially in order to create people's prosperity fairly and evenly. This factor often triggers community dissatisfaction with the position of the Regional People's Legislative Assembly (DPRD), given that the political elite who should set an example and role model for the community actually commits acts that are not commendable, enrich themselves, and even violate the law collectively.

These facts will be a benchmark for their ability to represent the people. This ability is very important to have to bring people's aspirations and interests. According to Soekanto, (2002: 268-269) that: Role (role) is a dynamic aspect of position (status), if someone carries out their duties and functions in accordance with their position, then he carries out a role. Likewise, with DPRD Members who have a status (status) within the 
community are expected to be able to carry out their duties and functions in order to be able to realize public welfare.

Therefore, strengthening and transforming political organizations in the community as an effort to anticipate various refraction of the concept of democracy resulting from the dominance of power in government. The purpose of strengthening social-political organizations as genuinely equal opportunity strategies so that people can participate according to their wishes in the hope that political equality can be achieved in democratic governance. To create this which is currently most possible is through political empowerment for the community.

However, the conception of political empowerment, of course, can be implemented if civilian supremacy in the state order is truly realized. The government always positions the community in a real form, which means guaranteeing equality of rights between individuals in strengthening an entity in the frame of plural and plural societies in a climate conducive to law. Based on this description, the authors draw attention to a deeper study of the implementation of political empowerment in creating community leadership as an analysis of the performance of members of the Ciamis Regency Regional Representative Council (DPRD) in the implementation of 2019 Legislative General Elections into scientific papers by setting one question main, namely: How is the Implementation of Political Empowerment of Members of the Regional Parliament (DPRD) of Ciamis Regency in the face of the 2019 Election?

\section{METHODOLOGY}

This research uses a descriptive qualitative approach. Technique the main data collection is in-depth interviews. In addition, the researchers also used observation and literature study collection techniques. Interviews were used to explore what collective actions were carried out by members of the Cimis Regency Regional Representative Council (DPRD) against political constituents in the face of the 2019 General Elections in each electoral district. The data analysis technique used in this study is the interactive analysis model (conclusion) of Miles and Huberman (1999) which consists of three lines of activities that occur simultaneously namely: data reduction (data reduction), data presentation (data display), and withdrawal conclusion/verification (conclusion drawing/verification).

\section{RESULTS}

So far, the concept of empowerment seems to be focused on activities to strengthen the economy, because community empowerment is seen as a form of resistance to poverty, deterioration, and inability of society, especially in developing countries or often referred to as third world countries. The failure of the model of economic development which is strongly influenced by the theory of modernization or the doctrine of developmentalism is the main reason for giving birth to the empowerment movement. The empowerment paradigm was born from the idea that development will run itself so that the community is given the trust in the form of the right to manage the 
natural resources they have and use them to build the community. Because up to now the main actors of development have been in the government/state considered to be unable to solve the problems of economic backwardness.

Keep in mind that empowerment is a process that cannot only be focused on one aspect of social life, but every part contained in people's lives needs to get the touch and attention of the empowerment activities themselves. Because basically community empowerment is the process of establishing a system that aims to increase community capacity in order to create a better quality of life. As stated by Soleh (2014: 175) that the goal of community empowerment is to create an independent, self-reliant society, and be able to adopt innovations in the form of development counseling, development communication, family welfare education, education about democratic values, skills education, training, and others.

However, community empowerment that has been implemented so far is less able to touch the activities of the community's political life, which is reflected in community participation in determining government representatives and involvement in decision making as if it is not an indicator of the success of the implementation of empowerment itself. Therefore the role and function of political empowerment for the community is an integral part of the framework of community empowerment. Political empowerment of society is actually a visualization of the approach of community participation in determining the policy direction of a government. Community involvement in real development can be seen from the extent of community participation in political life, especially in general elections and involvement in policy making, as well as control of the government.

For this reason, from the interview with one of the members of the Regional Representative Council (DPRD) of Ciamis Regency, he gave his statement on the implementation of political empowerment of the community, as follows: The main orientation of political empowerment is to motivate people to become human beings who are aware of their responsibilities through political education, political communication and political internalization to maintain stability and political mobilization, filter and determine leaders, form governments and participate in elections. Through strengthening political control, the public can voice their analysis and critical attitudes towards the government, especially with regard to government policies or programs through political or direct organizational channels.

From the statement, illustrates that political empowerment has been carried out by members of the Ciamis Regency DPRD, its essence is as a media manifestation of public awareness and concern and responsibility for efforts to improve the quality of political life in the administration of government and at the same time value formed from the impact of government policy on its implications for people's lives.

Furthermore, to find out the capacity of the impact felt by the community on the implementation of political empowerment carried out by members of the Ciamis Regency DPRD towards the constituents, an illustration was obtained from the results of interviews with one of the communities stating the following: 
It is undeniable that the authority to administer power by the government basically must be built from mutual trust and mutual support between the community and the government, so that building trust between the government and the community is considered as a way out to overcome the crisis of trust in government. So far, members of the Ciamis Regency DPRD have sometimes only provided guidance and approaches to the community when facing election periods, of course, to get support, while if they have been elected they rarely consolidate or make visits in order to win the people's aspirations. So that in the end, the community becomes apathetic in every election to elect candidates for DRPD both at the district, provincial and central levels. Because the work program they offer is nothing that can be felt concretely.

Based on the analysis, giving an overview of the role and function of community political empowerment should need deeper attention as part of the performance of members of the Ciamis Regency DPRD, because the political empowerment is as an opportunity / trust in the community to participate and be actively involved in determining Political quality of life is expected to restore public confidence in the government which tends to decline so far, because many reap condemnation and vote of confidence as a result of the behavior of government officials who are not commendable and even abuse authority to dirty political activities, such as money politics, buying and selling votes, black campaigns, etc., are often displayed in the administration of power in government.

Of course, to restore public trust is not an easy thing to do, but the great hope that the willingness of the community to participate in any political activity is considered to improve the quality of people's political life, and provide solutions or alternatives to the dilemmas in the current administration. It is undeniable that the authority to administer power by the government basically must be built from mutual trust and mutual support between the community and the government, so that building trust between the government and the community is considered as a way out to overcome the crisis of trust in government.

Besides that, there are other things that might contribute to the implementation of political empowerment that has been carried out by members of the Ciamis Regency DPRD, namely the involvement of political parties as media that can reach and invite the public to participate in any political activity. Therefore, on this occasion, there was also an interview with one of the administrators of political parties in Ciamis Regency so that it could be known about the description of the implementation of community political empowerment that had been carried out. The following is a statement from the results of interviews with the community, as follows:

Political parties should act as intermediaries for society with the state or as a channel for the political participation of the community that provides an opportunity to provide support or demands to the ruling government. In this case, political parties involve the interaction of the community both personally and organization to submit complaints, protests and even support for people's representatives who are in legislative institutions so that they always produce political decisions in the form of policies that favor the community in general, not on behalf of constituents or support group. But in 
fact, sometimes political parties never carry out various activities in order to increase the capacity of the community in politics, especially in the process of sheltering aspirations from the community to determine the leadership role or the people's representatives.

From this explanation, positioning political parties that exist and develop in the community as the initiator media of community participation to maintain the stability of the democratic political system. According to Surbakti (1999: 115), it was explained that "the idea of people's political participation through political parties in countries that implement a democratic political system has a strong base of political culture and ideology, that people have the right to participate in determining someone who will be their leader, and to determine the contents of general policies that affect their lives. To strengthen community participation and support, political parties must be able to show:

a. Clarity of vision, and mission of political parties.

b. Clarity of organizational structure, competencies, and strategies for winning politics.

c. Strengthening the management of political party organizations, including planning, organizing, implementing and supervising or controlling cadres of political parties.

d. Development of the number and quality of political party resources (human, financial, information, facilities and infrastructure)

e. Patterns of coaching and regeneration in organizations, and

f. Interaction between entities of political party organizations in preventing political conflicts in the community.

Therefore, the position of the community in the implementation of political empowerment plays a role as political control which is poured into the form of community participation as citizens relating to political actions both directly and directly to oversee the administration of government carried out by government officials who have political authority. In carrying out political control, the public is given the opportunity to recognize and know deeply about government political activities, as well as perceptions regarding political relevance to people's lives.

Meanwhile, in relation to the process of forming leadership originating from the people's mandate resulting from political empowerment, of course leaders needed in political parties are expected to be able to provide changes to the conditions of political parties that increasingly lose their identity and loss of trust as organized institutions in a political unit that aims to control the government and carry out general policies. Therefore, the presence of the leadership must be able to give legitimacy to political parties in order to be able to regain public trust so that political developments in the region will lead to a modern and complete democratic life that will be highly anticipated by members or cadres and sympathizers of political parties.

Referring to the statement, the concept of the leader of a political party should be able to reflect the character and personality in accordance with the philosophy of the Indonesian nation, as stated by Sahid (2011: 70-73) which affirms some of the characteristics of every leader in Indonesia, as follows: 
First, the One Godhead. This means that every leader in Indonesia is required to have firm religious beliefs, faith, and devotion to God Almighty. With the belief in religion as a way of life, it will create awareness that the essence of a leader is a person who has the same position before God, so that being able to understand the position of the leader is not superhuman or has absolute authority, but is humble and always modest. Thus will always better understand the conditions and conditions they lead.

Second, Ing Ngarso Sung Tulodo (front leader). Leaders who provide role models are able to stand in front as spearheads (shields) in the arena of struggle. Have great determination and courage and bear the heaviest responsibilities. Leaders are not only good at giving orders but are wise in giving instructions, advice, protection, and consideration.

Third, Ing Madya Mangun Kersa (Social Leader). A good leader will always be in the midst of his subordinates, take part in feeling the same fate, so as to be able to arouse and arouse subordinates' enthusiasm. Leaders who are big-spirited will know when and where and in what situations to always put themselves in accordance with the demands of subordinates.

Fourth, Tut Wuri Handayani (Rear Leader). Leading does not always have to be in front but kneeling at the right time to stand behind his subordinates. The leader stands up for auction not because of fear or cowardice, but as a provider of strength and moral support to strengthen every step and action of subordinates as a form of giving trust so that they take initiative and work more.

Fifth, Beware of Purba Wisesa (Beware and Power). Leaders are required to have visual acuity, be able to look forward (futuristic) as a form of vigilance in protecting organizations and subordinates. Leaders will be seen from how much ability they have to create, control and master the situation, so that they are seen as having advantages or advantages not possessed by subordinates, and are able to create charisma among subordinates as a form of authority.

Sixth, Ambeg Parama Arta (Being Right and Fair). Leaders must have the right and essential and fair nature. This means that leaders are able to distinguish between the important and not important, prioritizing the public rather than personal interests of each decision making.

Seventh, Prasa (Simple). In a leader, there must be a simple, sincere, sincere, tolerant and not lifestyle style. Simplicity must be able to be shown by the leadership as a form of incarnation of the original character of the Indonesian nation that can be used as indispensability for subordinates.

Eighth, Gemi, Nastiti, Ati-ati (Thrifty, Careful, Careful and Careful). Leaders will always be required to carry out work effectively and efficiently. The use of organizational resources, especially sources of wealth from the state, both in the form of wealth and capital, is managed sparingly and carefully. Apart from that, the accuracy of all actions and events that occur around them as a form of anticipation of the possibility of danger that occurs. And most importantly the leadership's prudent attitude in carrying out actions and actions based on common sense and logical reasoning is right. 
Ninth, Open (Communicative). Leaders provide opportunities for subordinates to express income, proposals or constructive criticism. The leader realizes that no human being is versatile but needs to open from learning and improving himself to the environment.

Tenth, Legawa (Rela and Tulus Ikhlas). A true leader is a person who is always capable and willing to give sacrifices and accepts for all defeats based on trust and trustworthy heart. Leaders do not have to always get praise but make every event in life a test that must be considered and carried out with full of selfless struggle.

Eleventh, Characteristic (Righteous and Virtuous). A leader as a noble and noble character is able to control himself and prioritize public interest above personal interests. Leaders who like to have nature and character are calm, neat, smooth and polite and do not punch power (Power) or imaging.

\section{CONCLUSION}

The results of the above analysis can be concluded that: the conception of political empowerment is part of community empowerment as a form of empowerment as an effort so that the community is able to be independent and understand every political activity in the administration of government. By opening understanding and positioning the community as part of the decision making through the provision of information and proper understanding of political behavior and attitudes, it will have an impact on the ability of the community to think rationally in carrying out political participation as part of the life of the nation.

Besides that, community political empowerment plays an important role as a framework to improve the level of public trust in the government, especially in shaping and giving birth to leaders who are in accordance with the mandate of the community. Where in this case the community is made as to the main actor who determines the quality of the leadership especially has a view that is in accordance with the current conditions of the community and can be understood as the intellectual characteristics of the members of the Regional People's Representative Council (DPRD) in Ciamis Regency. 
Page 708-717. ISBN: 978-602-6 988-75-1

Web Jurnal Online: jurnal.unmuhjember.ac.id

By: Agus Nurulsyam Suparman; Asep Nurdin; Intan Apriliani

Community Empowerment of Politics In Creating Public Leadership

(Analysis The Performance Members DPRD of Ciamis District In The Election 2019)

\section{References}

Alfian, M. Alfan. 2009. Menjadi Pimpinan Politik. Gramedia Pustaka Utama. Jakarta.

Budiarjo, Miriam. 2003. Dasar-Dasar Ilmu Politik. Gramedia Pustaka Utama. Jakarta,

Deliarnov. 2006. Ekonomi Politik; Mencangkup berbagai teori dan konsep yang kompreshensif. Erlangga. Jakarta..

Hasibuan. Malayu S.P. 2003. Manajemen Dasar Pengertian dan Masalah. Bumi Aksara. Bandung.

Heywood, Andrew. 2005. Political Theory An Introduction third Edition. New York: Palgrave Macmillan, Houndmills, Basingstoke, Hamphire.

Iskandar, Jusman. 2005. Teori dan Isu Pembangunan. Puspaga. Bandung.

Pasolong, Harbani. 2010. Kepemimpinan Birokrasi. Alpabeta. Bandung.

Thoha, Miftah. 2003. Birokrasi dan Politik di Indonesia. Raja Grafindo Persada. Jakarta.

Sahid, Kamarudin. 2011. Memahami Sosiologi Politik. Ghalia Indonesia. Bogor.

Surbakti, Ramlan. 1992. Memahami Ilmu Politik. Gramedia Widya Sarana Indonesia. Jakarta. 